DOI 10.4467/2543733XSSB.17.040.8338

ZORAN VUČKOVIĆ

Uniwersytet Jagielloński

\title{
NIEUDANA PRÓBA BUDOWY WSPÓLNEGO PAŃSTWA - SERBII I CZARNOGÓRY
}

Słowa kluczowe: Serbia i Czarnogóra, Serbia, Czarnogóra, transformacje polityczne na Bałkanach, Bałkany

\section{Główne czynniki wpływające na relacje pomiędzy Serbią a Czarnogórą}

Rozpad komunistycznej Jugosławii, zapoczątkowany odłączeniem Słowenii na początku lat dziewięćdziesiątych, z biegiem czasu nasilał się w coraz większym stopniu, i z perspektywy kolejnych dwudziestu lat doprowadził do uniezależnienia prawie wszystkich byłych republik Socjalistycznej Federacyjnej Republiki Jugosławii (Socjalistička Federativna Republika Jugoslavija - SFRJ). Drogę tę przebyła również Czarnogóra, u zarania lat dziewięćdziesiątych główny sojusznik Belgradu, opowiadający się za jednością federacji jugosłowiańskiej. W opracowaniu tym zostanie dokonana próba zidentyfikowania głównych czynników, który zaważyły na tym, iż wspólne państwo Serbii i Czarnogóry nie wytrzymało próby czasu. Dla osiągnięcia tego celu przeanalizowane zostaną stosunki pomiędzy dwiema republikami na tle prawnym, politycznym oraz gospodarczym.

W miarę jak kolejne republiki de facto stawały się niezależnymi państwami w coraz większym stopniu konieczne było ukształtowanie relacji pomiędzy Serbią a Czarnogórą, dwoma republikami, które po odłączeniu Słowenii, Chorwacji, Bośni i Hercegowiny oraz Macedonii pozostały formalnie nadal we wspólnej federacji. Niemniej jeszcze w momencie powołania FR Jugosławii w 1992 r. jej dwie części składowe, Serbia i Czarnogóra, miały wzajemnie niespójne systemy prawne. Głównym powodem był brak koherencji między konstytucjami obu republik a konstytucją federacji. Ustawa zasadnicza Serbii została uchwalona 28 września 1990 r. i nadawała prezydentowi Republiki duże kompetencje. W rezultacie w Serbii ukształtował się system półprezydencki ${ }^{1}$. Z drugiej strony

\footnotetext{
${ }^{1}$ Rozumiany jako dualizm egzekutywy, odpowiedzialność polityczna rządu przed parlamentem, możliwość rozwiązania parlamentu przez głowę państwa oraz wyłanianie prezydenta w drodze wyborów powszechnych, Ustav Republike Srbije, Beograd 1990; M. B ankowic z, Demokracja. Zasady, procedury, instytucje, Kraków 2006, s. 64.
} 
w Czarnogórze po 1990 r. nie uchwalono nowej konstytucji, jedynie zmodyfikowano (w 1990 r.) już obowiązującą ,socjalistyczną” z 1974 r. Pozycja prezydenta w zmodyfikowanej konstytucji nie była identyczna z pozycją prezydenta w Serbii. W konsekwencji po 1990 r. w Czarnogórze ukształtował się system parlamentarno-gabinetowy ${ }^{2}$. Nie bez znaczenia dla spójności systemu prawnego FR Jugosławii był fakt, że konstytucja Serbii została uchwalona dwa lata wcześniej niż konstytucja FR Jugosławii, w wyniku czego oba dokumenty znacznie się różniły ${ }^{3}$. Jako że niezgodność tych dwóch aktów prawnych nie została zniwelowana, doprowadzało to do napięć pomiędzy różnymi systemami prawnymi wspomnianych dwóch Republik. Takie w pewnych obszarach równoległe istnienie dwóch systemów prawnych skłoniło badaczy do postawienia tezy o zasadności postrzegania FRJ jako jednego spójnego systemu prawnego ${ }^{4}$.

Jednak nie tylko różnice na tle prawnym wpływały na relacje pomiędzy dwoma republikami. Począwszy od 1997 r., zauważalne były również znaczne rozbieżności na tle politycznym. Wówczas w Czarnogórze w wyniku rozłamu wewnątrz rządzącej Demokratycznej Partii Socjalistów (Demokratska Partija Socijalista - DPS) na frakcję „,socjalistyczną” oraz „neokomunistyczną” doszło do wystąpienia z partii tej ostatniej i powołania Socjalistycznej Narodowej Partii Czarnogóry (Socjalistička Narodna Partija Crne Gore - SNP CG). Po tych wydarzeniach na miejsce przewodniczącego DPS został wybrany Milo Djukanović, zamiast lojalnego wobec Miloševicia Momira Bulatovicia. Djukanović wygrał w październiku 1997 r. wybory prezydenckie, pomimo znacznego wsparcia dla Bulatovicia, napływającego z Serbii ${ }^{5}$. W tym samym roku DPS zdobyła większość w parlamencie, co pozwoliło jej ukształtować rząd. Wydarzenia te, w wyniku których władzę w Czarnogórze objęła bardziej demokratyczna opcja polityczna, doprowadziły do transformacji systemu politycznego w mniejszej Republice - z systemu autorytarnego w kierunku demokracji wyborczej ${ }^{6}$. Impuls zmian nie objął Serbii, w której autorytarne rządy nadal sprawował Milošević.

Po odsunięciu od władzy sojuszników Miloševicia w Czarnogórze zaczął się ostry konflikt władz dwóch Republik wchodzących w skład federacji. Uwidocznił się on najpierw na polu gospodarczym. Djukanović był zwolennikiem gospodarki rynkowej oraz otwarcia kraju na Zachód. W 1999 r. w Czarnogórze została wprowadzona niemiecka marka, a od 2002 r. euro; w rezultacie w federacji zaczęły funkcjonować dwa systemy walutowe. Ponieważ zwolennicy ówczesnego serbskiego prezydenta nie byli zdolni oddziaływać na politykę w małej czarnogórskiej republice, ów zaczął wykorzystywać instytucje federalne w celu kontrolowania tamtejszych działań politycznych. Instytucje te przed 1997 r. były marginalizowane, jako że wszystkie istotne decyzje były ustalane bezpośrednio ze sprawującym wówczas władzę w Czarnogórze Bulatoviciem. Po 1997 r. Milošević doprowadził do nieobecności posłów czarnogórskich z opcji Djukanovicia

\footnotetext{
${ }^{2}$ Rozumiany jako odpowiedzialność polityczna rządu przed parlamentem, udział rządu w stanowieniu prawa, prawo głowy państwa (monarchy bądź prezydenta) do rozwiązania parlamentu, Ustav Republike Crne Gore, Službeni List Crne Gore br 48/92, M. B a n k ow i c z, op. cit., s. 65-66.

${ }^{3}$ Zob. szerzej. V. Kutlešić, Stanje ustavnosti i zakonitosti i usklađenosti Ustava Srbije i Ustava Crne Gore sa Ustavom Jugoslavije, „Arhiv za pravne i društvene nauke”, 80 (3), 1994, s. 383-392.

${ }^{4}$ V. G o a t i, Izborna nadmetanja u Saveznoj Republici Jugoslaviji od 2000. do 2003., Beograd 2003, s. 10-11.

${ }^{5}$ Ibidem, s. 12.

${ }^{6}$ Ibidem.
} 
w Izbie Federalnej (w Izbie Obywateli ugrupowanie Miloševicia dominowało z racji bezpośredniego sposobu wyboru posłów oraz dzięki przewadze liczebnej deputowanych Serbii nad deputowanymi Czarnogóry).

Do całkowitego rozłamu pomiędzy Serbią a Czarnogórą doszło podczas kryzysu kosowskiego w 1999 r., który nasilił tendencje separatystyczne w Czarnogórze ${ }^{7}$. Bezskutecznie próbowała ona oddziaływać na politykę federacji i nawoływać do akceptacji przedstawionego przez USA planu pokojowego podczas negocjacji w Rambouillet. W obliczu nieuchronnego konfliktu Parlament Czarnogóry w marcu 1999 r. uchwalił rezolucję wzywającą do powrotu rezerwistów z Czarnogóry, którzy wówczas odbywali służbę w wojsku federalnym. W rezolucji Parlament Czarnogóry żądał od wojska jugosłowiańskiego, żeby podczas konfliktu z NATO nie korzystało z terytorium Republiki.

Po zakończeniu nalotów ponownie na pierwszy plan wysunęła się kwestia relacji pomiędzy dwiema Republikami. Czarnogóra opracowała wówczas propozycję zmian stosunków w federacji i w tej sprawie zainicjowała rozmowy z Belgradem. Milošević nie tylko odrzucił dialog, a nawet przeforsował poprawki konstytucji federalnej, stawiające Czarnogórę w jeszcze gorszym położeniu. Zmieniono sposób wybierania posłów do federalnej Izby Republik na bezpośredni ${ }^{8}$. W konsekwencji Izba Republik stała się kopią Izby Obywateli i przestała pełnić swoją zasadniczą funkcję obrony interesów mniejszej Republiki w federacji. Drugą istotną zmianą, wprowadzoną w lipcu 2000 r., mającą wpływ na relacje dwóch Republik, była zmiana sposobu wybierania prezydenta federacji. Według nowych regulacji prezydenta wybierano w wyborach bezpośrednich, przez co Czarnogóra w praktyce straciła możliwość wysunięcia własnego kandydata. Przez te poprawki Milošević pogwałcił prawa Czarnogóry do równorzędnej reprezentacji w ciałach federalnych ${ }^{9}$. Wszystkie wprowadzone zmiany opierały się na dysproporcji w liczbie mieszkańców pomiędzy dwiema Republikami. Czarnogórę zamieszkiwało w 2000 r. ponad 12 razy mniej mieszkańców niż Serbię $^{10}$. W proteście przeciwko tym zmianom konstytucyjnym, uchwalonym samodzielnie przez serbską stronę, koalicja czarnogórskich partii demokratycznych na czele z Milo Djukanoviciem - „Dla lepszego życia” (Da živimo bolje) zadecydowała o zbojkotowaniu wyborów na szczeblu federalnym. Jednak celem uniknięcia konfrontacji z Miloševiciem nie podjęto żadnych dodatkowych działań, aby nie doprowadzić do ewentualnego uniemożliwienia przeprowadzenia nieuznawanych przez siebie wyborów na obszarze Czarnogóry.

\section{Powstanie Związku Państw Serbii i Czarnogóry}

Jak zostało zaznaczone powyżej, większość problemów w relacjach pomiędzy dwoma republikami powstała w okresie funkcjonowania FRJ. Istotnym czynnikiem takiego stanu rzeczy były autorytarne rządy Miloševicia w Serbii, które uniemożliwiały jakiekolwiek

\footnotetext{
${ }^{7}$ E. B u jw i d-Ku rek, Państwa pojugosłowiańskie: Szkice politologiczne, Kraków 2008, s. 153.

${ }^{8}$ Wcześniej każda z republik według własnych regulacji delegowała 20 posłów.

9 V. Go at i, The Nature of the Order and the October Overthrow in Serbia, [w:] Revolution and order. Serbia after October 2000, red. I. Spasić, M. Subotić, Belgrade 2001, s. 52.

${ }^{10}$ W 2000 r. Czarnogórę zamieszkiwało ok. 612 tys. ludzi, Crna Gora, Zavod za statistiku, Statistički godišnjak 2011, Podgorica 2011, s. 41. W tym samym roku Serbię (bez Kosowa) zamieszkiwało ok. 7516 tys., Republički Zavod za statitiku, Demografska statistika 2009, Beograd 2010, s. 63.
} 
reformy w relacjach pomiędzy Belgradem a Podgoricą. Impulsem do metamorfozy okazała się jednak zmiana władzy w Belgradzie, w wyniku której do Parlamentu federalnego w 2000 r. z ramienia większej republiki dostali się posłowie Demokratycznej Opozycji Serbii (Demokratska opozicija Srbije, DOS). Jednak w Czarnogórze koalicja Milo Djukanovicia „Da živimobolje” zbojkotowała wybory i do Parlamentu federalnego (z puli miejsc należących do Serbii) weszły partie popierające Miloševicia - Socjalistyczna Narodowa Partia Czarnogóry oraz Serbska Partia Narodowa, co spowodowało poważny problem dla DOS-u w kwestii ukształtowania stosunków z Czarnogórą. Pierwszym wyjściem było utworzenie koalicji z SNP CG oraz SrNS (Serbska Partia Narodowa, Srpska narodna stranka). Argumentem przemawiającym za takim posunięciem była presja jak najszybszej reintegracji całego kraju z organizacjami międzynarodowymi w celu uzyskania pomocy międzynarodowej. Druga opcja prowadziła w kierunku unieważnienia wszystkich aktów prawnych wynikłych z lipcowych zmian konstytucyjnych z 2000 r. (na skutek których Milošević zmarginalizował wpływy Czarnogóry w federacji). W wyniku nacisków Demokratycznej Partii Serbii (Demokratska stranka Srbije, DSS), koalicja DOS obrała współpracę z SNP CG oraz SrNS w Parlamencie federalnym. W taki sposób Serbia de facto uznała wyniki wyborów w Czarnogórze, zbojkotowane przez sprawującą władzę na poziomie republiki koalicję Da živimo bolje. 5 listopada 2000 r. DOS uformował rząd federalny razem z SNP CG i SrNS, a urząd premiera objął Zoran Žižić.

Świadomy coraz głośniejszych żądań Czarnogóry dotyczących opuszczenia federacji, albo co najmniej jej przemodelowania, Koštunica udał się z wizytą do Podgoricy 17 października 2000 r. Wcześniej, uczestnicząc na szczycie UE w Biarritz, podczas którego uchwalono doraźną pomoc dla FRJ w wysokości 200 mln euro, Koštunica potwierdził, że zgadza się na ewentualne rozpisanie referendum w sprawie niepodległości Czarnogóry oraz akceptuje zamiar zmiany nazwy FRJ na Serbia i Czarnogóra ${ }^{11}$. Podczas spotkania z Koštunicą prezydent Czarnogóry Djukanović uznał zmianę władzy w Belgradzie oraz podkreślił, że on i kierowana przez niego Demokratyczna Partia Socjalistów będą uczestniczyć w sprawowaniu władzy na poziomie federacji jedynie po uprzednim jej zreformowaniu. Spotkanie odegrało dużą rolę we wzajemnych stosunkach, gdyż dopiero wtedy Djukanović uznał Koštunicę za prezydenta federacji (wcześniej odmawiał legalności wrześniowym wyborom). Jednocześnie prezydent Czarnogóry podkreślił swoje niezadowolenie z decyzji DOS-u (de facto DSS-u) o współpracy z SNP CG i SrNS ${ }^{12}$.

Okazało się, że nawiązanie współpracy przez DOS z dawnymi sojusznikami Miloševicia w Czarnogórze na poziomie federacji ,,posiadało daleko idące negatywne konsekwencje dla przetrwania FR Jugosławii"'13. Po pierwsze, SNP CG i SrNS utrudniały razem z DSS w Parlamencie federalnym uchwalenie ustawy o współpracy z Trybunałem w Hadze, która miała umożliwić wydanie Miloševicia Trybunałowi. Po drugie, sama współpraca DSS-u z popierającymi Miloševicia partiami z Czarnogóry stanowiła dla polityków z mniejszej republiki sygnał, że w Belgradzie po 2000 r. nie doszło do zasadniczej zmiany sposobu prowadzenia polityki. Ten obraz starał się zmienić Djindjić. Podczas swojego

11 All in accord-on procrastination, ,The Economist” 21 X 2000, http://www.economist.com/node/397830, (dostęp 16.11.2016).

${ }_{12}$ R. Bideleux, I. Je ffries, The Balkans: A Post-Communist History, Oxon 2007, s. 276.

13 Ibidem. 
exposé w Skupštinie Serbii w styczniu 2001 r. nowo mianowany szef rządu podkreślił, że Belgrad „,(..) kolegom z Czarnogóry proponuje ponowne ułożenie stosunków według zasady najmniejszego ryzyka, jakim jest reforma państwa"14.

Deklaracje te nie były wystarczająco przekonujące dla polityków rządzących w Czarnogórze. W 2001 r. Djukanović odstąpił od wcześniejszych deklaracji modyfikacji istniejących stosunków w państwie na rzecz wyprowadzenia Republiki z FRJ. Planował on uzyskać w tej sprawie akceptację społeczeństwa w referendum ${ }^{15}$. Taka zmiana podejścia spowodowana była nadchodzącymi wyborami w Czarnogórze, które zdominował temat pozostania w federacji lub jej opuszczenia. W wyborach kwietniowych w $2001 \mathrm{r}$. wzięło udział 82\% obywateli Czarnogóry. Powodem tak wysokiej frekwencji była waga wyborów, w których dwie główne siły w kraju, skupione wokół Djukanovicia oraz Bulatovicia, opowiadały się za dwiema różnymi koncepcjami jego rozwoju. Pierwszy z nich optował za niepodległością, drugi zaś skłonny był wzmacniać więzi z Serbią. Wybory wygrało stronnictwo Djukanovicia, uzyskując minimalną przewagę różnicą 1,5 punktu procentowego. Świadczyło to o głębokim podziale w czarnogórskim społeczeństwie.

Po wyborach Djukanović przystąpił do rozmów z Sojuszem Liberalnym (Liberalni Savez, LS), który warunkował swoje wejście do rządu natychmiastowym rozpisaniem referendum na temat niepodległości Republiki. Pod naciskiem Stanów Zjednoczonych, Unii Europejskiej oraz innych instytucji międzynarodowych, przekonanych, iż rozpisanie referendum mogłoby zdestabilizować cały region, rząd Czarnogóry wybrał proces reform wewnętrznych wspólnie z Serbią. Prezydenci Serbii i Czarnogóry, z pomocą mediacji Javiera Solany, szefa dyplomacji UE, podpisali w dniu 14 marca 2002 r. Podstawy wyjściowe do uregulowania stosunków Serbii i Czarnogóry (Polazne osnove za uredjenje odnosa Srbije i Crne Gore) ${ }^{16}$. Po podpisaniu porozumienia, w wyniku braku poparcia LS, rząd Czarnogóry podał się do dymisji i nowe wybory parlamentarne zostały rozpisane na październik 2002 r. Tym razem Djukanović uzyskał większą przewagę, zdobywając 47\% oddanych głosów w stosunku do 38\% głosów oddanych za koalicją Bulatovicia. Niepodległościowy Sojusz Liberalny był ostatnią partią, która przekroczyła próg wyborczy z 6\% oddanych głosów ${ }^{17}$. Mieszkańcy Czarnogóry jasno tym razem określili swój stosunek do wspólnego państwa z Serbią. Według podpisanego porozumienia Czarnogóra mogła rozpisać referendum najwcześniej trzy lata od uchwalenia konstytucji, co władze Republiki otwarcie deklarowały.

W dniu 4 lutego 2003 r. Skupština Serbii i Czarnogóry uchwaliła Kartę Konstytucyjna Serbii i Czarnogóry (Ustavna Povelja Srbije i Crna Gore). Nowe państwo miało charakter dwupodmiotowej unii. Władze federalne miały kompetencje w obszarze wspólnej polityki obronnej, zagranicznej i gospodarczej. Władza ustawodawcza należała do Parlamentu federalnego. Według art. 20, skład Skupštiny Narodowej w pierwszych dwóch latach od momentu uchwalenia Karty Konstytucyjnej wybrany został w sposób pośredni, propor-

${ }^{14}$ Expose mandatara za sastavvlade Zorana Djindjića (audio zapis przemówienia w Skupsztynie), 25 I 2001 , Virtuelni muzej Zorana Djindjića, http://www.zorandjindjic.org, (dostęp 02.02.2016).

15 E. Bujwid-Kurek, Państwa..., s. 153.

16 Dokument ten nazwany został „Porozumieniem belgradzkim” (Beogradski sporazum), zob. Polazne osnove za uredjenje odnosa Srbije i Crne Gore, „Bilten ministarstva spoljnih poslova” 15 III 2002 r., http://www. mfa.gov.rs/Srpski/Bilteni/Srpski/b150302_s.html, (dostęp 29.09.2016).

17 E. Bujwid-Kurek, Państwa..., s. 160. 
cjonalnie do składów parlamentów republik ${ }^{18}$. Pierwszy skład Skupštiny Serbii i Czarnogóry wyglądał następująco: DOS - 37 mandatów, DSS - 17 mandatów; SPS (Socjalistyczna Partia Serbii) - 12 mandatów; SRS (Serbska Partia Radykalna, Srpska radikalna stranka) - 8; SDP (Socjaldemokratyczna Partia, Socijaldemokratske partije Srbije) - 5; Liga Socjaldemokratów Wojwodiny - 3; Demochrześcijanska Partia - 2; Alternatywa Demokratyczna - 2; Sojusz Węgrów Wojwodiny - 2; Klub poselski „Srbija” - 1; Nowa Serbia - 1; Socjalistyczna Partia Narodowa - 1. Posłowie z Czarnogóry: Socjalistyczna Partia Narodowa - 9; Socjaldemokracja - 4; Serbska Partia Narodowa - 3; Partia Narodowa -2 ; LS $-2^{19}$. Według postanowień konstytucji, od 2005 r. członkowie Parlamentu federalnego wybierani byli w wyborach bezpośrednich. Z 126 deputowanych 35 miejsc zarezerwowanych było dla Czarnogóry, podczas gdy z Serbii pochodziło 91 posłów ${ }^{20}$. Do głównych kompetencji Parlamentu federalnego należało zatwierdzenie składu rządu oraz wybór prezydenta wspólnego państwa. Pierwszym prezydentem został Svetozar Marović 17 marca 2003 r. ${ }^{21}$ Władza wykonawcza była skupiona w rządzie, którego pracą kierował prezydent. W związku z asymetrią ludnościową dwóch republik porozumienie wprowadzało mechanizmy gwarantujące równowagę Czarnogóry we wspólnych instytucjach $^{22}$. Część instytucji państwowych przeniesiono do Podgoricy.

\section{Rozpad konfederacji Serbii i Czarnogóry}

Wraz z powołaniem nowego Parlamentu Serbii i Czarnogóry, na początku marca 2003 r., Koštunica ustąpił ze stanowiska prezydenta FRJ. Na czele konfederacji Serbii i Czarnogóry stanął Svetozar Marović, który został wybrany przez połączone izby Parlamentu konfederacji.

Pochodzący z Czarnogóry członkowie Narodowej Rady ds. Kooperacji z Trybunałem w Hadze 23 września 2004 r. zrezygnowali ze swoich stanowisk w proteście przeciwko polityce Serbii, dotyczącej odmowy współpracy z Trybunałem. Według przedstawicieli czarnogórskich, integracja Serbii i Czarnogóry z UE opóźniała się właśnie z tego powodu. Uznając zasadność powyższych obaw, jeszcze w tym samym miesiącu Komisja Europejska uchwaliła podejście dwutorowe (twin-track approach) w stosunku do Serbii i Czarnogóry. Pozwoliło to obu republikom na wspólne negocjacje z UE w tym samym czasie - z utrzymaniem odrębnego statusu w procesie integracji. Innymi słowy, postęp $\mathrm{w}$ integracji jednej z republik nie był warunkowany postępem drugiej.

18 Art. 10 Ustavna Povelja, Službeni list Srbije i CrneGore, br.1/2003, s. 3.

${ }^{19}$ Opinie na temat możliwości przetrwania Serbii i Czarnogóry obrazowały doniesienia mediów na temat pierwszego posiedzenia Parlamentu federalnego. Belgradzka „Politika” określała je jako „,nowy początek”, zaś „Vijesti” z Podgoricy skupiały się na negatywnych wydarzeniach towarzyszących posiedzeniu, V. D i d a n ov i ć, Start trogodišnjeg ogleda, ,Vreme”, 6 III 2003, http://www.vreme.com/cms/view.php?id=334400, (dostęp 20.01.2011).

${ }^{20}$ E. Bujwid-Kurek, Państwa..., s. 153.

21 Ibidem.

22 Należy zaznaczyć, że podobne mechanizmy zawarte były także w Konstytucji FR Jugosławii z 1992 r. Jednak ze względu na autorytarny sposób sprawowania władzy przez Slobodana Miloševicia nigdy nie zostały zastosowane. Ibidem, s. 163. 
22 lutego 2005 r. szef rządu Czarnogóry Milo Djukanović zaproponował rozluźnienie więzów łączących oba państwa, co oznaczało krok w kierunku niezależności. Następnego dnia Koštunica określił ten akt złamaniem Porozumienia z Belgradu. 28 lutego minister spraw zagranicznych Czarnogóry Miodrag Vlahović w wywiadzie dla Radia Wolna Europa oświadczył, że Republika ta zamierza stać się członkiem UE i NATO, będąc samodzielnym krajem ${ }^{23}$.

Zgodnie z porozumieniem zawartym w 2003 r. referendum w Czarnogórze miało się odbyć najwcześniej w 2006 r., o czym również postanowiły władze Republiki. W tej kwestii jednak miały one problem ze znalezieniem konsensusu z opozycją. Głównymi trudnościami były: określenie minimum wymaganej większości głosów dla powodzenia referendum, poziomu niezbędnej frekwencji wyborczej oraz dopuszczenie do głosowania Czarnogórców zamieszkałych w Serbii (czego domagał się również Belgrad). W sprawie mniejszości czarnogórskiej Komisja Wenecka, ciało doradcze Rady Europy, wydała opinię nieprzychylną wobec wniosków strony serbskiej ${ }^{24}$. Z kolei w wyniku negocjacji przedstawiciel UE w Czarnogórze, słowacki dyplomata Miroslav Lajčak zaproponował 55\% większość kwalifikowaną przy 50\% frekwencji wyborczej dla ewentualnego sukcesu referendum. Datę referendum Parlament czarnogórski ustalił na 21 maja 2006 r. Po przeliczeniu głosów okazało się, że 55,5\% głosujących w Czarnogórze opowiedziało się za opuszczeniem wspólnoty z Serbią. Zgromadzenie Narodowe Czarnogóry proklamowało niepodległość 3 czerwca 2006 r. ${ }^{25}$ Prezydent Tadić w dniu 23 maja 2006 r. w swoim przemówieniu uznał wyniki referendum ${ }^{26} .5$ czerwca specjalna sesja Skupštiny Serbii formalnie zaakceptowała rozpad Serbii i Czarnogóry i ogłosiła niepodległość Serbii. Spadkobiercą podmiotowości prawno-międzynarodowej wspólnego państwa według Karty Konstytucyjnej była Serbia ${ }^{27}$.

\section{Podsumowanie}

Podsumowując, w okresie istnienia Serbii i Czarnogóry można wymienić kilka problemów, które miały największy wpływ na relacje między tymi republikami:

- Systemy konstytucyjne obu republik były ze sobą niespójne. Wpływało to na sposób funkcjonowania federacji.

- Po 1997 r. kierownictwo obu republik przejawiało rozbieżne wobec siebie interesy. Jeżeli w Czarnogórze zaczęły ujawniać się z coraz większą siłą proeuropejskie dążenia oraz tendencje demokratyczne, to w Serbii pod rządami Miloševicia nadal dominowały trendy izolacjonistyczne i autorytarne.

${ }^{23}$ Vlahović: Crna Gora ne želi da bude nečiji pristup na more, Radio Slobodna Evropa, 2 VI 2012, http:// www.slobodnaevropa.org/archive/news/20050210/500/500.html?id=838779, (dostęp 02.06.2012).

${ }^{24}$ Draft opinion on the compatibility of the existing legislation in Montenegro concerning the organization of referendums with applicable international standards, European Commission for democracy through Law, http://www.venice.coe.int/docs/2005/CDL(2005)094-e.pdf, (dostęp 02.06.2012).

${ }_{25}$ Republika Crna Gora. Referendum o državnom statusu, Kancalarija za demokratske institucije i ljudska prava OSCE/ODIHR, http://www.osce.org/sr/odihr/elections/montenegro/20099, (dostęp 02.06.2016).

${ }^{26}$ Tadic says he accepst Montenegrin citizens'decision, "Bilten ministarstva spoljnih poslova" $24 \mathrm{~V} 2006$, http://www.mfa.gov.rs/Bilteni/Engleski/b240506_e.html\#N2, (dostęp 02.06.2016).

27 Ustavna Povelja... 
- Dotyczyło to również systemów walutowych, co stanowiło trzeci znaczący problem wpływający na relacje dwóch republik. Od 2001 r. Czarnogóra zaczęła posługiwać się euro jako obowiązującą walutą, tymczasem w Serbii nadal w użyciu był dinar.

- Czynnikiem istotnie wpływającym na los wspólnego państwa Serbii i Czarnogóry były również coraz silniejsze dążenia niepodległościowe w mniejszej republice.

- Władze obu republik inaczej postrzegały kwestię rozwiązania problemu Kosowa. Przed 1999 r. skutkowało to odmową wysłania żołnierzy z Czarnogóry do odbywania służby poza granicami kraju. Niemniej po zażegnaniu konfliktu w Kosowie różnice nadal istniały. Jeżeli Serbia opowiadała się za kontynuowaniem walki o utrzymanie prowincji w granicach kraju i w tym celu gotowa była poświęcić perspektywę wejścia do struktur Unii Europejskiej, to władze Czarnogóry zdeterminowane były nie tracić czasu na walkę o utrzymanie Kosowa. W tym kontekście należy wspomnieć również o całkowicie odmiennym sposobie postrzegania Trybunału w Hadze przez Belgrad oraz Podgoricę. Jeżeli Podgorica opowiadała się za pełną współpracą (i tym samym ułatwiała sobie proces integracji z UE), to Belgrad był przeciwko. Taka postawa większej republiki blokowała całemu państwu proces integracji z UE.

- Nie bez znaczenia również był fakt, iż za czasów Miloševicia władze Czarnogóry były zdominowane w instytucjach federalnych przez Serbię; to doprowadziło do wzrostu niezadowolenia w mniejszej republice. Dodatkowo polityka niezważania na interesy mniejszej republiki była kontynuowana po części również po 2000 r., co utwierdziło Podgoricę w słuszności obrania własnej drogi.

\section{Bibliografia}

Dokumenty:

Demografska statistika 2009, Republički Zavod za statitiku, Beograd 2010.

Draft opinion on the compatibility of the existing legislation in Montenegro concerning the organization of referendums with applicable international standards, European Commission for democracy through Law, http://www.venice.coe.int/webforms/documents/default.aspx?pdffile $=$ CDL-AD(2005)041-e, (dostęp 02.06.2016).

Expose mandatara za sastav vlade Zorana Djindjića (audio zapis przemówienia w Skupsztynie), 25 I 2001, Virtuelni muzej Zorana Djindjića, http://www.zorandjindjic.org, (dostęp 02.02.2016).

Polazne osnove za uredjenje odnosa Srbije i Crne Gore, „Bilten ministarstva spoljnih poslova” 15 III 2002 r., http://www.mfa.gov.rs/Srpski/Bilteni/Srpski/b150302_s.html, (dostęp 29.09.2016).

Referendum o državnom statusu, Republika Crna Gora, Kancalarija za demokratske institucije i ljudska prava OSCE/ODIHR, http://www.osce.org/sr/odihr/elections/montenegro/20099, (dostęp 02.06.2016).

Statistički godišnjak 2011, Zavod za statistiku, Podgorica 2011.

Ustav Republike Crne Gore, Službeni List Crne Gore, br. 48/92.

Ustav Republike Srbije, Beograd 1990.

Ustavna Povelja, Službeni list Srbije i Crne Gore, br. 1/2003.

Monografie:

Bankowicz M., Demokracja. Zasady, procedury, instytucje, Kraków 2006.

Bideleux R., Jeffries I., The Balkans: A Post-Communist History, Oxon 2007.

Bujwid-Kurek E., Państwa pojugosłowiańskie: Szkice politologiczne, Kraków 2008, s. 153.

Goati V., Izborna nadmetanja u Saveznoj Republici Jugoslaviji od 2000. do 2003., Beograd 2003. 
Artykuły:

All in accord - on procrastination, ,The Economist” 21 X 2000, http://www.economist.com/ node/397830, (dostęp 16.11.2016).

Didanović V., Start trogodišnjeg ogleda, „Vreme” 6 III 2003, http://www.vreme.com/cms/view. php?id=334400, (dostęp 20.01.2011).

Goati V., The Nature of the Order and the October Overthrow in Serbia, [w:] Revolution and Order. Serbia after October 2000, red. Spasić I., Subotić M., Belgrade 2001, s. 45-59.

Kutlešić V., Stanje ustavnosti i zakonitosti i usklađenosti Ustava Srbije i Ustava Crne Gore sa Ustavom Jugoslavije, „Arhiv za pravne i društvene nauke”, 80 (3), 1994, 383-392.

Tadic says he accepts Montenegrin citizens' decision, „Bilten ministarstva spoljnih poslova”, $24 \mathrm{~V}$ 2006, http://www.mfa.gov.rs/Bilteni/Engleski/b240506_e.html\#N2, (dostęp 02.06.2016).

Vlahović: Crna Gora ne želi da bude nečiji pristup na more, Radio Slobodna Evropa, 2 VI 2012, http://www.slobodnaevropa.org/archive/news/20050210/500/500.html?id=838779, (dostęp 02.06.2016).

\section{Zoran Vučković}

\section{The Unsuccessful Attempt at Building a New State Serbia and Montenegro}

\section{Summary}

After the disintegration of communist Yugoslavia a new entity was created - the Federative Republic of Yugoslavia. The newly created state consisted of two Republics previously belonging to the Socialist Federal Republic of Yugoslavia - Serbia and Montenegro. At the beginning, when FR Yugoslavia was created, both Belgrade and Podgorica shared a common goal which was unifying the federation - an effort to territorially expand and cover territories which the Serbian or Montenegrin population were living on. However, in time this changed. First, the democratic option with Milo Djukanović at helm took power in Montenegro in 1998 and afterwards, in 2000 the situation dramatically changed in Belgrade as well, as the democratic opposition overthrew Slobodan Milošević. This meant that a new reassessment of relations within the Federation needed to take place. However, immediately after the 2000 election, the newly elected government in Serbia was not willing to make any big changes in the structure of the country as it needed to focus on more pressing issues within the Republic. Over time this lead to a gradual increase in tensions between Belgrade and Podgorica. After the initial stall a fresh approach to the reform was undertaken which led to the creation of Serbia and Montenegro in 2003. It turned out that the newly created state would not be long lived as in 2006 Montenegro opted for independence. The article examines the process of reform that has led to the creation of Serbia and Montenegro in a search for explanation of main factors that have contributed to the fact that the newly created state did not pass the test of time.

Keywords: Serbia and Montenegro, Serbia, Montenegro, politic transformations in the Balkans, the Balkans. 